\title{
The philosophy of Vladimir Solovyov as the subject matter of Yuri Govorukha-Otrok's literary criticism
}

\author{
Elizaveta Zakharova ${ }^{1,2}$ (iD \\ Published online: 31 August 2020 \\ (c) The Author(s) 2020
}

\begin{abstract}
Vladimir Solovyov's aesthetic theory has been the subject of much research. However, aesthetic views of the philosopher's contemporaries are analyzed less frequently. The purpose of this article is to consider the views of Yuri Govorukha-Otrok on the aesthetic ideas of Solovyov in relation to the issues of national identity. Despite the discrepancy in the interpretation of such concepts as "culture," "national idea," or "truth" the very fact of the polemics between the philosopher and the literary critic proves the continuity of the religious and the philosophical dimensions of literary criticism. This study analyzes Govorukha-Otrok's critical papers of Solovyov's work, allowing for the possibility to compare integral ideological and philosophical systems in order to understand the influence of Govorukha-Otrok's views on the whole body of Solovyov's ideas.
\end{abstract}

Keywords Theurgy $\cdot$ Culture $\cdot$ Philology $\cdot$ The national idea $\cdot$ Religious philosophical criticism

\section{Yuri Govorukha-Otrok and Vladimir Solovyov in 1880-90s}

The 1880-90s was the period that marked "the general turn of thought from politics to culture, from social problems to ethics and existential, ontological understanding of man and his place in the universe" (Shchennikov 2005, p. 241). That was the time when positivism and rationalism began to suffer a crisis, while symbolism was about to come into being with its resistance to everyday-life matters and insistent inquiry about the essence of the human being and the laws that underlie human life. At that very time Yuri Nikolaevich Govorukha-Otrok (1854-1896), a literary and

Elizaveta Zakharova

lizazenova@gmail.com

1 Department of Russian Literature, A. M. Gorky Institute of World Literature of the Russian Academy of Sciences, Moscow, Russia

2 Faculty of Philology, MSU, Leninskie Gory 1/5, Moscow, Russia 1119991 
theatrical critic, publicist, and prose writer, began his professional career that fully corresponded to the spirit of the time.

The articles by Vasily Rozanov, Lev Tikhomirov, and Iosif Fudel published in the 1986 volume Memories of Govorukha-Otrok give a comprehensive idea of how Govorukha-Otrok's works had been received among his contemporaries. In his book Literary Exiles Rozanov called Govorukha-Otrok "the best critic of the 1880-90s" (Rozanov 2001, p. 77). This means that, despite the many circumstances that prevented his works from becoming widely known, he occupied a special niche in the minds of his contemporaries.

Modern scholarship makes a new turn to the works of Govorukha-Otrok. Thus, Smolina (2001, pp. 176-210) and Kulakova (2010) describe specific features in his approach to art criticism, including the desire to find an expression of "perennial" values in a literary work. Selected articles by Govorukha Otrok are being published simultaneously with papers on the peculiarities of his method. The first volume of the author's collected works came out in 2005, including several short stories and plays (Govorukha-Otrok 2005). In 2012, for the first time, a two-volume collection of his principal journalistic, literary-critical, and religious-philosophical works (Govorukha-Otrok 2012) was published. In 2015, a book of his prosaic and journalistic works appeared. The latter volume is focused on, among other things, in the series of discussions between Govorukha-Otrok and Vladimir Solovyov. Nearly three dozen articles cover an extremely wide range of topics; among the most notable are the following: theological and religious issues, the significance of the State, and the meaning of war. Thematic homogeneity allows us to regard all of these polemical discussions with Solovyov as a single complex. Govorukha-Otrok himself repeatedly refers to the previously written papers of the philosopher, which proves the dialogical nature of their interaction.

\section{Polemical dialogue between philosopher and critic}

Although the style of Govorukha-Otrok's works is extremely polemical, and the judgments, as a rule, are painted in harsh tones, we can say that, by challenging the position of Solovyov on a significant number of issues, the literary critic increasingly clarified his own position and specified his standpoint. The Solovyov-GovorukhaOtrok debate was first highlighted by Ivanova in the preface to the first volume of the latter's collective works. The author points out that it was the religious crisis that deepened among the intelligentsia which caused Govorukha-Otrok's total rejection of Solovyov's ideas: “Govorukha-Otrok saw the peril of Solovyov's attacks on the Church in their novel nature, as the latter-under the guise of innovation-was trying to impose Catholic and his own idiosyncratic cultural ideas on Orthodox Christianity" (Govorukha-Otrok 2012, p. 65). The polemicizing attitude is largely a consequence of the circumstances of Govorukha-Otrok's personal life. In relation to many contemporaries, he held a defensive stance, not being in full solidarity with anyone. Nevertheless, his writings on Vladimir Solovyov occupy an exceptional position in this line. 
This study analyzes Govorukha-Otrok's critical articles on the work of Solovyov, considered from the point of view of comparing two ideological and philosophical systems as integral frameworks. The purpose of this paper is to get closer to understanding the influence of Govorukha-Otrok's views on the whole body of Solovyov's ideas. An attempt is made to understand his critical interpretation of Solovyov's aesthetic vision. In order to clarify the essence of Govorukha-Otrok's discrepancy with Solovyov in the interpretation of such concepts as "culture," "religion," and "national idea," it is also examined how he perceived the romantic works of Ivan Goncharov and Nikolai Gogol. The comparison of two ideological systems allows us to determine their relationship at the structural and content level, as well as to conclude this systems' logical features and methodological principles. Besides, the hypothesis of continuity (from Solovyov to Govorukha-Otrok) in the religious and philosophical line of literary criticism is justified.

A series of articles about Vladimir Solovyov occupies a special place in the legacy of Govorukha-Otrok. The matter is that the critic himself was a philosopher or at least a literary critic with a philosophical attitude. The beginning of GovorukhaOtrok's professional literary career dates back to the second half of the 1880s. It was at that time that he became a regular author of the "Moskovskiye Vedomosti" newspaper, and, beginning in 1889, he was the head of the literary and theatrical department. In less than 10 years of cooperation with the newspaper and other periodicals, he managed to publish a significant number of articles of various genres and on numerous topics.

Govorukha-Otrok's encyclopedic knowledge of the world and Russian literature, as well as the texts of the Holy Scriptures, was an essential factor that influenced his aesthetic taste, values, and worldview. The works of Thomas Carlyle also played an important role in the evolution of the critic's views. As Govorukha-Otrok admitted, his predecessors and teachers were Fyodor Dostoyevsky, Apollon Grigoryev, and Nikolai Strakhov. Many contemporaries stressed that Govorukha-Otrok adhered to a strict system of ideological principles based on Orthodox Christian faith. Indeed, it was this adherence of Govorukha-Otrok to the basics of a religious worldview that determined all his professional activities.

The history of relations between Solovyov and Govorukha-Otrok can be described as a long polemical dialogue. The topics touched upon in some articles were later developed in other papers, which resulted in a series of works, united in content, and then in structure. However, while there is a vast scientific literature on the mutual influence between Solovyov's philosophical and literary-critical system and those of Dmitry Merezhkovsky, Rozanov, Nikolai Berdyaev, Konstantin Leontyev, and Nikolai Fyodorov (Yurina 2019), the story of intense interaction between Solovyov and Govorukha-Otrok is still out of scholarly sight.

The annotated index of names form Govorukha-Otrok's two-volume collection of works "What did the Russian writers believe in?" allows us to conclude that Solovyov interested Govorukha-Otrok not only as a philosopher, poet, and publicist, but also as one of the central figures among contemporaries and intellectuals. It is safe to say that Govorukha-Otrok perceived Solovyov as an influential thinker with a markedly different approach and worldview. The style of Govorukha-Otrok is characterized by openness and straightforwardness in the presentation of one's point 
of view. The body of works on Solovyov was no exception, as the critic declares his disagreements with the philosophical system in a categorical and very frank manner: "The major mistake of Mr. Solovyov is that by Christianity he means Catholicism" (Govorukha-Otrok 2012, p. 287); "I wish Mr. Solovyov will recall that the 'universal idea', to which he refers so often, proclaimed a 'unity in spirit and truth' of equal people, but not a mechanical union that denies nationality and consists in flattening all living things, all that is bright and original" (ibid., p. 291). Each essay on Solovyov is permeated by the author's personal attitude to the point of the statement, especially at moments when it comes to the mental and spiritual order of the philosopher himself.

\section{Patriotism, religion, belles-lettres in the context of Solovyov- Govorukha-Otrok debate}

Govorukha-Otrok is against one of Solovyov's central ideas, namely the "common unity of mankind": "Solovyov completely overlooks the fact that the principle of nationality guided all these conquerors, and in its pagan sense" (Govorukha-Otrok 2012 , p. 289). It is important to note here that Govorukha-Otrok's work can be most precisely defined as a piece of philosophical literary criticism. However, when talking about Solovyov's views, the critic seems to overlook the literary aspect of his professional specialization, almost entirely submitting to philosophical reflections. Repeatedly, the critic's judgments take the form of aphorisms and ontological maxims: "it is our sin that in the historical course of our evolution we have broken away from the source of our enlightenment, from the Orthodox Church" (ibid., pp. 294). "We are all religious by habit, by upbringing, and we all have no difficulty in understanding our religiosity, our faith" (ibid., p. 727); "having lost the ability to live a spiritual life, a person is already living without dogma, without the law, setting a law only for his psychic life, which is not guided and enlightened by anything" (ibid., p. 451). But it is important to see the unity of the method once chosen, even behind this shift from literary criticism to the philosophical field. Both in the conversation about literary works and in the critical analysis of Solovyov's works, Govorukha-Otrok sets the knowledge of man at the top of mind. Criticism is always interested in the psychic organization of a literary character or the author of the text being analyzed. Thus, separate fragments of the articles allow us to form an idea of Govorukha-Otrok's personal attitude to the range of problems under consideration: "The essence of Solovyov's propaganda" (ibid., p. 295); "Solovyov is one of [Pyotr] Chaadayev's epigones" (ibid., p. 295); "It is amazing how Solovyov's position is deeply comic, as is the position of any person sitting on two chairs. His ideal is different from that of his allies, which I have already pointed out to him many times" (ibid., p. 364).

Solovyov's vision, and most importantly the way it is presented, is extremely contagious, says Govorukha-Otrok. That's why he wishes so eagerly to challenge the philosopher, who arouses interest with his charismatic judgments, as well as their presentation. Yet it is in this phenomenon of contagion that the desire of GovorukhaOtrok to join the irreconcilable polemics is concealed. His goal is to protect as many 
potential followers as possible from Solovyov's philosophical system, as well as to dissuade actual proponents. By joining in the discussion of Chaadayev and Westernism (ibid., p. 298), Govorukha-Otrok moves to a conceptual core: the question of nationality in general, and the existence of original art in particular. Here the following thesis of Solovyov is disputed: "the modern decline of Russian literature indicates that it cannot be called national and original at all" (ibid., p. 307). Our emphasis here will be on how Govorukha-Otrok perceived Solovyov's views on Russian belles-lettres. We must emphasize at this point that Govorukha-Otrok never divided the problem of patriotism from faith and religion.

In response to Solovyov's denial of the existence of the national art GovorukhaOtrok states: "These people, Gogol and Pushkin, were no patrioteers, no vulgar optimists, but they knew how to love Russia and the Russian people with penetrating love, seeing all the ulcers, all the diseases of the beloved being, and thus loving and sympathizing even more" (ibid., p. 304). Govorukha-Otrok interprets the key ideas of Solovyov's book The National Question as follows: "Solovyov proved that Russia is no more than a 'relaxed colossus, ... the Russian people have not been able to perceive any enlightening beginning, have not created any culture,... the Russian people are only ethnographic material that can be processed into something and suitable only through the principles of a foreign culture" (ibid., p. 304). As for the problem of uniting churches, Western and Eastern, Govorukha-Otrok considers it from the point of view of the latter's ability to be independent. If the answer to the question of whether the Russian people have been able to create a true culture in their centuries-old history is positive, then the question of the need to merge the two branches of Christianity makes no sense. However, the decisive argument that prevents Govorukha-Otrok from any kind of sympathy with the position of Solovyov is the absence of an implicit call to repentance (ibid., p. 305).

Govorukha-Otrok analyzes the ideological and the theoretical system of Solovyov, namely his views on Russian philosophy, science, and history, in separate articles. One can make the assumption that such a range was required, first of all, for an extremely wide and, therefore, justified conclusion about the main thing, namely Russian art or Russian belles-lettres. The most detailed discussion on this subject is in the work "Russian art as judged by Vladimir Solovyov." According to Govorukha-Otrok, Solovyov treats Russian literature in an unfairly condescending way. In particular, he criticizes Solovyov's view on Russian novelists as the epigones of European ones (ibid., pp. 307-308). Govorukha-Otrok contrasts this approach with evidence of exceptional identity "in literature (Pushkin, Gogol and their school), music (Glinka), and... dramatic art (Mochalov, Shchepkin, Martynov, etc.)" (ibid., p. 310). Here it should be noted that Solovyov made an exception to Dostoevsky, whose novels are no fancy stories, since "they embrace all that is dark, morbid, tormenting and ugly about our social life" (Solovyov 1990, p. 293). Yet Govorukha-Otrok's perception of Dostoevsky, whom he deemed a prophetic writer, was ambiguous. On the other hand, he shows the influence of European novelistic tradition on Dostoevsky, as well as on Goncharov and Turgenev (Govorukha-Otrok 2012, p. 313). On the other hand, Dostoevsky, intending to keep up with Pushkin's and Gogol's tradition of capturing the people's worldview, failed, according to Govorukha-Otrok, to give an equal weight: "the spirit of mystical insight as a 
precondition of the creative work was only an echo in Dostoevsky" (ibid., p. 740). Govorukha-Otrok vigorously defends his opinion that the sources of Russian belleslettres are in the works of Pushkin, who, on the one hand, was the first to perceive a "European heritage," and on the other hand, was critical of it, paving the subsequent development of genuine Russian literature. Govorukha-Otrok also disputes Solovyov's words that Balzac and Thackeray are the predecessors of Pushkin, Gogol, and Lermontov (ibid., pp. 311-312). He regards the phenomenon of Russian art as unique and powerful, with its independence beginning with Pushkin.

Govorukha-Otrok even nicknamed Solovyov "the theologizing publicist" (ibid., p. 336). So, the title of the article "What is the teaching of Vladimir Solovyov?" shows clearly that Govorukha-Otrok deemed the spiritual and moral education through reading journalistic articles extremely important. A concerned, sometimes biased, and emphatically personal attitude to the writings of Solovyov is due, first of all, to the fact that Govorukha-Otrok observes in the fundamental moments of the philosophical system of his antagonist the proximity to his own attitudes and principles. However, there are plenty of harsh epithets and sometimes caustic sarcastic remarks within the entire "Solovyov series": "the obscure words of Mr. Solovyov..."; "His speech is ambiguous and opaque" (ibid., p. 361); "At the end of his article, as if answering my question 'what is the teaching of Mr. Solovyov?', he says that he has no teaching. And it is true" (ibid., p. 300); "Mr. Solovyov is a little Jesuit, but not a spooky, but a comical one" (ibid., p. 379).

The elements of the sermon-like style are characteristic of the texts of the Govorukha-Otrok himself. Moreover, for him, the obligatory presence of a religious component in solving social problems was an indisputable fact. However, the difference of views is found in the question about the sources of true enlightenment: "What else, if not the Church, brought enlightenment to Russia? What else, if not Christianity, accepted by the Russian people, gave it strength, the opportunity to come together and throw off the Tatar yoke?" (ibid., p. 402). It can be assumed that the harshness of judgments in interpreting the religious issues associated with Solovyov is fully explained by the following thesis: "Every Christian, when attacking his faith, must defend it by the power of his mind, not expecting any authorization..." (ibid., p. 529). Nevertheless, one can see a fundamental similarity of the methods of Solovyov and Govorukha-Otrok, as indirectly testified by the words of the latter: "Criticism is a kind of philosophical reasoning" (ibid., p. 443).

\section{The question of Russian art}

Returning to the essence of the polemic between Govorukha-Otrok and Solovyov regarding the phenomenon of Russian art, it will be necessary to dwell on the issue, discussed in the first half of the 1890s, of art in general and its reflection in the literary-critical vision of Solovyov, who "consciously assumed... intermediate, religious-aesthetic ideas dating back to Odoyevsky, Chaadayev, Grigoryev and Dostoyevsky, called to reconcile extreme points of view in aesthetics through a synthesis of their strengths, to combine the two main lines (materialistic and idealistic) in Russian aesthetics" (Yurina 2013, p. 33). An artistic theory was unacceptable to 
Solovyov, who "believed that the final goal of creative activity is the change in reality" (ibid., p. 34, 44).

The detailed exposition of Solovyov's aesthetic views can be found in Kormin's work. The author's focus is on Solovyov's interpretation of the metaphysical nature of aesthetic phenomena: "Solovyov represents a priori the obvious structure of the aesthetic, namely, harmony within the being, rooted in the soul replete with feelings"; "Man himself is a symbol of God, and this initial symbolism gives an a priori form on which the very possibility of aesthetics can be realized" (Kormin 2001, p. 26). Defining the essence of Solovyov's aesthetics, the researcher calls it "holy harmony" (Vinogradova 2009, p. 7).

The ironic tone of the articles on Solovyov is a clear indication of GovorukhaOtrok's absolute rejection of the thinker's philosophical program: "All serious people have long understood that our gifted philosopher is only fiddling around; however, there are many who see something significant in this trifling, and it is worthwhile for them to understand this matter a little bit" (Govorukha-Otrok 2012, p. 284). The critic succinctly formulates the main theses that Solovyov advocates in his prosaic and poetic texts:

"the absence of... the idea of theocracy is explained by Mr. Solovyov with the presence, in his opinion, of the internal disagreement and discord in the Eastern Church, which are the reason, he thinks, for the inertness of this Church's principles. Solovyov sees the restoration of unity and harmony in the Eastern Church's assimilation of the newly listed advantages of the Western Church, and best of all, in the union with the Western Church on the basis of mutual concessions." (ibid., p. 286)

Govorukha-Otrok strongly opposes the idea of theocracy defended by Solovyov because it conceals "the traditional papal desire for secular power, which is neither mysterious nor sublime, but rather a belittling and defaming of the idea of the Universal Church" (ibid., p. 287).

Even more sharply, the critic rejects the idea that the universal idea must prevail over the national one. This aspect is essential, as the concept of the national idea occupies the central place in the literary-critical and ideological systems of Govorukha-Otrok (Novikov 2012, p. 26). While "for Solovyov an ethnic group is the most important factor of human life... it is within the framework of the ethnic group that national culture is formed" (Malaya 2001, pp. 158-169). However, the difference between the two positions is that, according to Solovyov, "the moral and Christian solution of the national question will be real in the society of the world theocracy, which will be the result of the reunification of the Orthodox and Catholic churches" (ibid., pp. 158-169).

But the more similar the ideas of the opponents are, the more arresting the argument. Neither Solovyov, nor Govorukha-Otrok can agree with the position known as "art for art's sake." We can also point out that both Govorukha-Otrok and Solovyov both act as preachers in the majority of their written works. The worldview of Govorukha-Otrok was the decisive factor that determined the character of his views on literature and the tasks of literary criticism. Thus, Govorukha-Otrok's articles on Goncharov's The Precipice show how the critic first singles out the figure of a 
nihilist among his contemporaries and then reflects on the problem of nihilism as a general phenomenon. He also defines not only what helped Vera to struggle with Mark Volokhov, but also what should be used to fight nihilism as a phenomenon in general. Thus, Govorukha-Otrok claims that the strength of Vera lies in the soil that

"gave birth to her, in the legends, in the mood that influenced the maturity and development of her spiritual life. She embraced what she called the "eternal truth', the truth of Christ, she embraced the beauty of this truth, and no Mark could separate her from this truth... Religiosity, warm and lively faith, rooted in her heart since her infancy, saved her... In the novel, nihilism retreats, retreats in the face of warm, childish faith, conscious mind, developed through contact with the true education." (Govorukha-Otrok 2012, pp. 543-544)

The popular opinion that Goncharov "in Oblomov embodied his idea of the harmful features of the Russian national character, such as passivity and laziness, the products of the system of national education, which prevent one from fulfilling inner zeal and showing one's best qualities" (ibid., p. 515) is refuted by GovorukhaOtrok, who polemically argues that in the novel Oblomov "the author himself, not realizing it, only because of his talent, which took him far beyond his plan, showed us a type that epitomizes the beauty of soul of the Russian educated man" (ibid., p. 531). As Otradin noted, "Govorukha-Otrok's article revealed the soil-bound, nativist ideas" (Otradin 1991, p. 12), which can be spotted, in particular, in the critic's reasoning about the main character of the novel. We can see that the categories, such as "the people," "the national idea" and "the typical," were the determining factors in the aesthetic system of Govorukha-Otrok.

\section{Continuity of the philosophical aspect of literary criticism}

It has already been mentioned above that Govorukha-Otrok often philosophizes in his literary-critical judgments. But it is important to note that it is in such "theological" moments that he agrees with Solovyov. The titles of the articles on Solovyov show us that Govorukha-Otrok was mainly interested in the thinker's ideas on morality.

Here too, one cannot help noticing the methodological closeness of the philosopher and the critic. The supreme task of the latter is to demonstrate how the reader can benefit from a true and profound immersion in the world created by the writer. Literary criticism seemed to him to be more than an isolated consideration of the merits and demerits of the work or a diligent analysis of the text. Govorukha-Otrok was a philosophical writer in literary criticism, as his essays included not only the solution of artistic and aesthetic problems, but also the formulation of questions of universal importance.

The author of the monograph Literary and Artistic Creativity of Vladimir Solovyov in the Context of Russian Literature in the Second Half of the 19th Century states that Solovyov became the founder of the religious and philosophical critique which emerged in the turn of the nineteenth-twentieth centuries, and gives a list of principles that distinguish this trend (Yurina 2019, p. 401). At the same time, 
Zvereva says that the literary and critical activity of Govorukha-Otrok is close to the religious and philosophical version of the critique (Zvereva 2006). The general opinion was that "the religious and philosophical direction in criticism of the turn of the nineteenth-twentieth centuries did not have a distinct leader who would formulate a general program and declare a new method of analysis of the literary text" (Yurina 2019, p. 400). Among the current studies on Govorukha-Otrok, there is no clear opinion on how to interpret the tradition in which the critic worked. The image of Govorukha-Otrok as a philosopher-critic can be considered the most common view among scholars. Thus, for example, one of the most interesting topics for critics was the problem of the discrepancy between the ideal and reality.

However, before making a conclusion about the focus of Govorukha-Otrok's literary criticism, it is necessary to describe his religious and philosophical approach. On the one hand, the authors point out the turn towards the "de-aestheticization of literature": "the interpretation of artistic work from the standpoint of a certain philosophical system with its distinctive tradition," as well as "the interpretation of artistic work in philosophical terms" (Oblasova 2012, p. 10). However, the most precise definition of the essence of this approach is the observation made in the work of Hansen-Love on the different degree of de-aesthetization in philosophical interpretations, which is largely determined by the generation factor (Hansen-Love 1999, p. 38).

Thus, one can see that the combination of such ideological systems as soil-bound nativism, Slavophilism, Christianity, and conservatism formed the peculiarity of Govorukha-Otrok's views and had a decisive impact on his literary-critical activity. He evaluated art on the basis of Christian teaching. If we at least limit ourselves to this set of facts, and trace what exactly lies in the essence of the approaches to the texts by Govorukha-Otrok and Solovyov, then we will see the homogeneity of methods. Publicist approach and passion are combined with a mandatory focus on social impact. Yet while Govorukha-Otrok builds mainly on religion, Solovyov's foothold is history (Zenkovsky 2001, p. 468). The main unifying feature is the practical orientation of philosophical quests. Vladimir Solovyov, the younger contemporary of Govorukha-Otrok, can be paradoxically considered his teacher of philosophical criticism. Thus, it can be argued that the basis of many years of journalistic polemics on numerous issues is a deep-rooted underlying cause that relates not only to the divergence in the interpretation of religious issues, but also to the antagonism of the teacher and the student.

Acknowledgements This research was conducted at the A.M. Gorky Institute of World Literature of the Russian Academy of Sciences with financial support of the Russian Science Foundation (RSF, the Project No. 17-18-01432-П).

\section{Compliance with ethical standards}

Conflict of interest The author declares that she has no conflict of interest.

Open Access This article is licensed under a Creative Commons Attribution 4.0 International License, which permits use, sharing, adaptation, distribution and reproduction in any medium or format, as long as 
you give appropriate credit to the original author(s) and the source, provide a link to the Creative Commons licence, and indicate if changes were made. The images or other third party material in this article are included in the article's Creative Commons licence, unless indicated otherwise in a credit line to the material. If material is not included in the article's Creative Commons licence and your intended use is not permitted by statutory regulation or exceeds the permitted use, you will need to obtain permission directly from the copyright holder. To view a copy of this licence, visit http://creativecommons.org/licen ses/by/4.0/.

\section{References}

Govorukha-Otrok, Y. N. (2005). Sobranie sochinenii [Collected works] (Vol. 1). Belgorod.

Govorukha-Otrok, Y. N. (2012). Vo chto verovali russkie pisateli [What did the Russian writers believe in] (Vol. 1, 2). Saint-Petersburg.

Hansen-Love, A. (1999). Russkij simvolizm. Sistema pojeticheskih motivov. Rannij simvolizm [Russian symbolism. The system of poetic motives. Early symbolism]. Saint-Petersburg: Akademicheskiy proyekt.

Kormin, N. A. (2001). Filosofskaya estetika Vladimira Solovyova [Philosophical aesthetics of Vladimir Solovyov]. Moscow: IFRAN.

Kulakova, I. I. (2010). Tsennostnye orientiry kritiki [Value orientations of criticism]//Zhizn' provintsiala kak fenomen dukhovnosti: sbornik statei po materialam Vserossiyskoy nauchnoi konferentsii s mezhdunarodnym uchastiem. November 12-14, 2009. N. Novgorod. http://www.fil.unn.ru/flf/kraev edenie/files/publications/sbornik_2009.pdf.

Malaya, V. G. (2001). Russkaya ideya i natsional'nyj vopros v tvorchestve V. Solovyova [Russian idea and the national question in the legacy of Vl. Solovyov]. Solovyovskie issledovaniya, No. 1 (pp. 158-169).

Novikov, M. V., and Shvetsov V. V. (2012). Vladimir Solovyov i diskussiya o russkom natsionalizme [Vladimir Solovyov and the discussions of Russian nationalism]. Yaroslavskij pedagogicheskij vestnik, No. 4. Tom I (Gumanitarnye nauki) (pp. 24-31).

Oblasova, T. V. (2012). Russkaja literaturnaja kritika rubezha XIX-XX vekov: Puti samopoznanija: religiozno-filosofskoe napravlenie [Russian literary criticism at the turn of 20th century: The ways of self-understanding. Religious-philosophical trend]. TOGIRRO Bulletin, 5(23).

Otradin, M. V. (1991). "Oblomov" v zerkale vremeni [Oblomov in the mirror of time]. In: Roman I.A. Goncharova "Oblomov" v russkoi kritike [Goncharov's novel 'Oblomov' in the Russian critique. Leningrad: LGU (pp. 3-19).

Rozanov, V. V. (2001) Sobranie sochineniy [Collected works]. Vol. 13: Literaturnye izgnanniki: N. N. Strahov. K. N. Leontyev. Moscow.

Shchennikov, G. K., and Shchennikova L. P. (2005). Istoriya russkoj literatury XIX veka [History of Russian literature of the 19 th century]. Moscow.

Smolina, K. A. (2001). Y. N. Govorukha-Otrok i zadachi konservativnoj literaturnoj kritiki [Y. N. Govorukha-Otrok and the goals of the conservative literary critics]. In: Rossijskij konservatizm $v$ literature i obshchestvennoj mysli XIX - nachala XX veka. Moscow (pp. 176-210).

Solovyov, V. S. (1990). Sochineniia. [Works], in 2 vols. Vol. 2. Edited by A.F. Losev and A.V. Gulyga. 2nd ed. Moscow: Mysl'.

Vinogradova, E. V. (2009). Teurgicheskaya estetika Vladimira Solovyova [Theurgic aesthetics of Vladimir Solovyov]. Solovyovskie issledovaniya., 4(24), 4-15.

Yurina, N. G. (2013). Literaturno-kriticheskaya kontseptsiya V.S. Solovyova: istoki, stanovlenie, razvitie [V. Solovyov's literary-critical concept: origins, formation, development]. Saransk.

Yurina, N. G. (2019). Literaturno-hudozhestvennoe tvorchestvo V. S. Solovyova v kontekste russkoj slovesnosti vtoroj poloviny XIX veka (estetika, poetika, stil) [Literary and artistic creativity of V. Solovyov in the context of Russian literature of the second half of the 19th century (aesthetics, poetics, style)]. Saransk.

Zenkovsky, V. V. (2001). Istoriya russkoj filosofii [History of Russian philosophy]. Harkov, Moscow.

Zvereva, Y. V. (2006). Filosofskaya kritika 90-h godov XIX veka (na materiale statej Y.N. GovoruhiOtroka i A.L. Volynskogo): [Philosophical criticism of the 1890s (a case study of Y. N. GovorukhaOtrok and A. L. Volynsky articles)]. Author's abstract, Perm. 
Publisher's Note Springer Nature remains neutral with regard to jurisdictional claims in published maps and institutional affiliations. 